"Exchange rate movements in the presence of the zero lower bound"

\begin{tabular}{|c|c|c|}
\hline AUTHORS & Jens Klose & \\
\hline ARTICLE INFO & $\begin{array}{l}\text { Jens Klose (2017). Exchange ra } \\
\text { bound. Banks and Bank System }\end{array}$ & $\begin{array}{l}\text { ne presence of the zero lower } \\
\mathrm{i}: 10.21511 / \mathrm{bbs} .12(1) .2017 .10\end{array}$ \\
\hline DOI & http://dx.doi.org/10.21511/bbs.1 & \\
\hline RELEASED ON & Friday, 24 March 2017 & \\
\hline & $(\mathrm{cc})$ EY-NC & \\
\hline LICENSE & $\begin{array}{l}\text { This work is licensed under a C } \\
\text { International License }\end{array}$ & Attribution-NonCommercial 4.0 \\
\hline JOURNAL & "Banks and Bank Systems" & \\
\hline ISSN PRINT & 1816-7403 & \\
\hline ISSN ONLINE & $1991-7074$ & \\
\hline PUBLISHER & LLC "Consulting Publishing Cor & Perspectives" \\
\hline FOUNDER & LLC “Consulting Publishing Cor & Perspectives" \\
\hline & & $\begin{array}{l}\text { ニ-ニ } \\
\text { ニ-E }\end{array}$ \\
\hline NUMBER OF REFERENCES & NUMBER OF FIGURES & NUMBER OF TABLES \\
\hline 9 & 2 & 4 \\
\hline
\end{tabular}

(c) The author(s) 2023. This publication is an open access article. 


\title{
Exchange rate movements in the presence of the zero lower bound
}

\begin{abstract}
Exchange rates are expected to adjust according to the stance of monetary policies, which are in normal times differences in interest rates set by the central banks. This interest rate parity does, however, no longer hold if central banks approach the zero lower bound on interest rates and switch to measures of quantitative easing. Therefore, the author estimates exchange rate changes based on the different stance of the monetary base, which is an indicator of differing monetary policies in the countries. The results reveal that indeed exchange rates movements in the Dollar-Euro-Rate can be explained by differences in the monetary base, since the zero lower bound has become binding. However, the influence depends crucially on whether the monetary base is increased or decreased and whether the other central bank is also expanding or reducing its balance sheet at the same time.
\end{abstract}

Keywords: monetary base, exchange rate, Fed, ECB.

JEL Classification: E52, E58, F42.

\section{Introduction}

Central banks all over the world cut interest rates rapidly in the wake of the financial crisis. Soon many of them approached the zero lower bound forcing them to the territory of unconventional monetary policy. In such an environment, the interest rate policy of a central bank is no longer its main target, but other measures, i.e., the evolution of the monetary base.

Since central banks do no longer set interest rates freely in this situation, standard economic concepts relying on interest rates can no longer be applied. One of these concepts is the well-known interest rate parity being used for the determination of exchange rate movements. Although the concept of the interest rate parity can be used to estimate exchange rate movements of different time horizons, all interest rates used in this concept are influenced to some extent by the interest rate differences of the corresponding central banks.

In this article, we will focus on the determination of the U.S. Dollar-Euro exchange rate in the presence of the zero lower bound. To do so, we will change the traditional interest rate parity to a monetary base parity, meaning that exchange rates movements are determined by the differing stance of monetary policy of the U.S. Federal Reserve (Fed) and the European Central Bank (ECB). Both central banks expanded to a differing degree their monetary base after the collapse of Lehman Brothers in September 2008 using quantitative measures to a different extent ${ }^{1}$. So, this expansion coincides with large cuts in the policy interest rates to historical lows leading to both central banks at least facing the zero lower bound (Figure 1).

(c) Jens Klose, 2017.

Jens Klose, Prof., Dr., THM Business School, University of Applied Sciences, Germany.

${ }^{1}$ The effect of quantitative easing measures on the exchange rate is well documented: see, e.g., Neely (2010), Chen et al. (2012) or Fratzscher et al. (2013) for the U.S. and Joyce et al. (2011) for the UK.

This is an Open Access article, distributed under the terms of the Creative Commons Attribution-NonCommercial 4.0 International license, which permits re-use, distribution, and reproduction, provided the materials aren't used for commercial purposes and the original work is properly cited.
So, both central banks had to switch to other policy instruments in order to further support the economy. Apart from measures of communication ${ }^{2}$, i.e. the forward guidance introduced in the crisis by both central banks, quantitative measures play a key role in this respect. Irrespective of whether this quantitative easing is done via outright purchases like the Fed mostly does it or via refinancing operations, as it is mainly the case for the ECB, this monetary expansion leads to an increase in the monetary base, so either in an increase in currency in circulation, reserve requirements with the central bank or excess reserves held at the central bank. So, the monetary base is the indicator of whether monetary policy is accommodative or restrictive instead of the policy rate, which signals the monetary stance in normal times. Therefore, a monetary base parity can be developed.

This article proceeds as follows: in section 1, the evolution from the traditional interest rate parity to the monetary base parity is shown. Section 2 discusses the data used and their properties. Section 3 estimates the monetary base parity with respect to the US Dollar-Euro exchange rate. A special focus is given to the interaction of monetary policies of both central banks, i.e., whether both are expansionary/restrictive or are acting in different directions. The last section finally concludes.

\section{From interest rate to monetary base parity}

In normal times, the traditional interest rate parity condition between an investment in the U.S. or the Euro area should hold ${ }^{3}$ :

$$
E R_{t} \cdot\left(1+I_{U S_{t}}\right)=E_{t} E R_{t+1} \cdot\left(1+I_{E A_{t}}\right)
$$

${ }^{2}$ In this article, we abstract from all sources of communication changes and their influence in easing financial conditions. See for this channel Campell et al. (2012), Hanson and Stein (2012) or Swanson and Williams (2014).

${ }^{3} \mathrm{We}$ abstract from concerns whether the covered or uncovered interest rate parity is used and present only the uncovered version, since differences in both are not essential to our approach. 


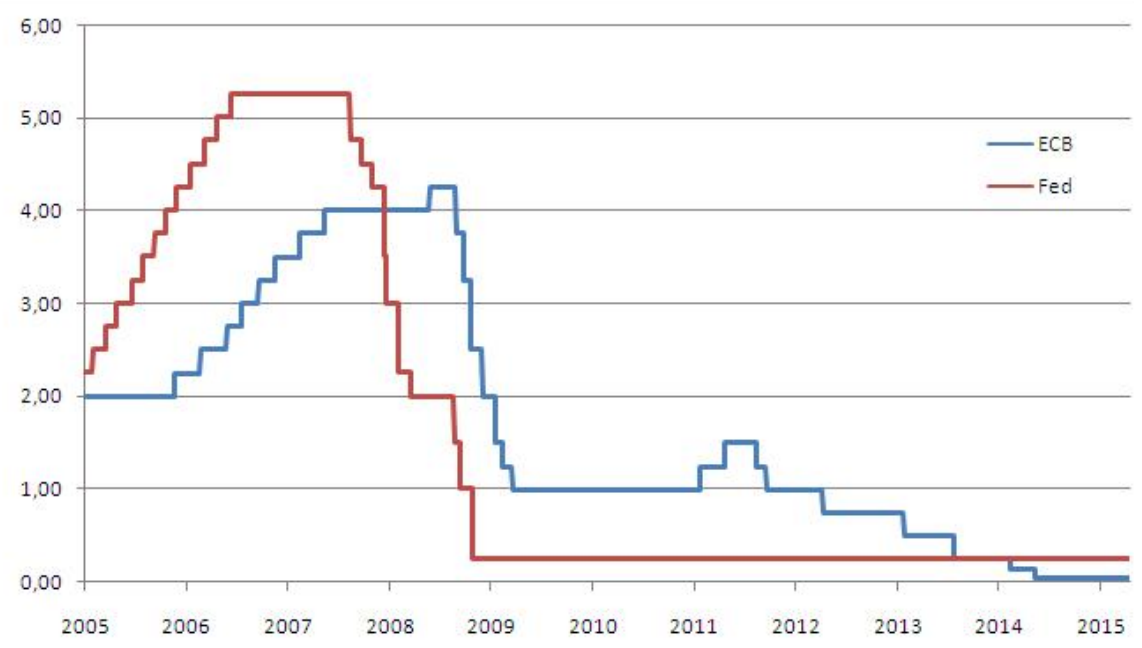

Fig. 1. Fed funds rate for the Fed, main refinancing rate for the ECB

Following this argumentation, investors should be indifferent between using the current exchange rate $E R_{t}$ and investing in the U.S., thus, earning $I_{U S_{t}}$ or investing in the Euro area earning $I_{E A_{t}}$ and transferring the whole investment after maturity at the today expected rate in the next period $E_{t} E R_{t+1}{ }^{1}$. Simply rearranging, the assumption of rational expectations and delay equation (1) by one period leads to:

$E R_{t}=E R_{t-1} \cdot \frac{\left(1+I_{U S_{t-1}}\right)}{\left(1+I_{E A_{t-1}}\right)}$.

So, the current exchange rate is determined by the exchange rate in the prior period and the relationship of U.S. to Euro area returns. However, when hitting the zero lower bound, the latter relationship is bound to unity even though monetary policies of the Fed and the ECB might be diverging due to a different degree of quantitative easing. In this context, the monetary base is the policy tool used by the central banks. Therefore, we can substitute the interest rates which are essentially growth rates of capital returns from one period to the other with the growth rate of the monetary base in the U.S. and the Euro area.

$E R_{t}=E R_{t-1} \cdot \frac{\left(1+M B_{U S_{t-1}}\right)}{\left(1+M B_{E A_{t-1}}\right)}$.

Please note that $M B_{U S_{t-1}}$ and $M B_{E A_{t-1}}$ can be negative in contrast to the interest rates, which can hardly fall below zero. This is the case when the monetary base decreases between two periods, i.e., when central banks are exiting from quantitative easing.

$e r_{t}=e r_{t-1}+r_{U S_{t-1}}-r_{E A_{t-1}}$.

Setting $1+M B_{X_{t-1}}=R_{X_{t-1}}$ taking the logs (lower case letters) so that results can be interpreted as elasticities leads to equation (4), which can be used

${ }^{1}$ See, e.g., Levich (2011) for an application of the interest rate parity in the recent crisis period. for our estimation purposes. We will come back to this equation in section 3 , but, next we turn to the data description.

\section{Data}

Equation (3) and (4) show that three time series are needed: the exchange rate and the monetary base of the Fed and the ECB, respectively. We use weekly data, because both central banks publish their monetary base as part of the Fed's factors effecting reserve balances and the ECB's weekly financial statement in this frequency. The monetary base of the Fed is calculated as the sum of the balance sheet positions "currency in circulation" and "reserve balances with federal reserve banks". Doing so leads to almost similar results than the bi-weekly published monetary base of the Fed. The ECB's monetary base is equivalent to the sum of "banknotes in circulation", "current accounts", "deposit facility" and "fixed term deposits".

While both central banks publish their monetary base on a weekly basis, the days in which they do so differ. The Fed reports Wednesday values in their balance sheet and the ECB gives always the Friday values. So, there is possibly a frequency mismatch if the Fed adjusts their monetary policy, especially on Thursdays. However, there is no indication that this is the case.

The time series of the monetary base is presented in Figure 2. It is obvious that both central banks used the monetary base as a policy tool in late 2008. More precisely, both central banks increased their monetary base significantly for the first time in week 39 of the year 2008. This is exactly the week where the investment bank Lehman got bankrupt. ${ }^{2}$. Afterwards, the monetary base of both central banks stays at higher levels for the remaining sample period. However, the

${ }^{2}$ Baba and Packer (2009) find also a role of central bank actions in explaining interest rate parities after the Lehman collapse. 
size of the increase in the monetary base differs considerably. While, in the U.S., the increases in the three rounds of quantitative easing starting in December 2008, November 2010 and September 2012 are clearly visible, in the Euro area, the largest increase is found in late 2011 and the beginning of 2012, which reflects the two longterm refinancing operations with a duration of three years. This is also the reason why the monetary base in the Euro area has fallen since the end of 2012, because the liquidity provided is repaid by the financial institutions. However, with the QE-program announced in January 2015 and its subsequent prolonings, the ECB balance sheet is expected to increase even further until the end of 2017.

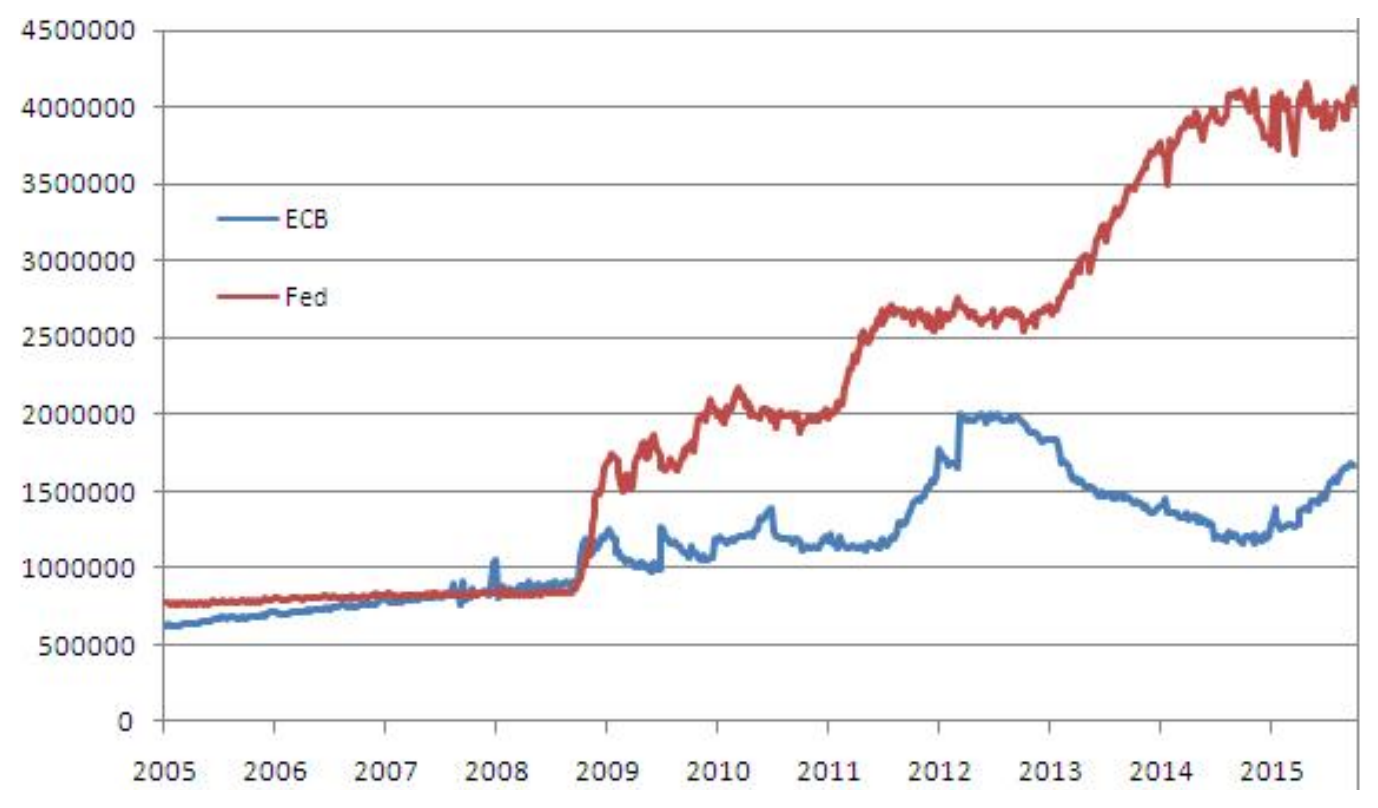

Fig. 2. Monetary base of the Fed and the ECB

But key interest rates of both central banks were just falling from higher levels in week 39 of the year 2008 and had not yet approached the zero lower bound. So, for a transition period, both central banks adjusted the monetary base and the key interest rates. For this reason, we conduct a robustness check, which starts only in week 20 of the year 2009. In this week, the ECB adjusted their key interest rate to 1 percent, which was the low point for quite a long time, while the Fed had already introduced their interest range of $0-0.25$ percent.

As becomes obvious from Figure 2, our sample runs from 2005 to the beginning of 2015 . So, we cover more than three years before both central banks adjusted their monetary policy to at least implicitly targeting the monetary base. We do so to check whether changes in the balance sheets also had significant effects before the Lehman crisis. However, we do not expect that this is the case. The end of the sample period is chosen to match the period before the ECB started purchasing bonds via the new QE-program. The relevant exchange rate is the Friday noon U.S. Dollar/Euro exchange rate, thus, corresponding with the ECB balance sheet reporting. All variables used for estimation purposes proved to be stationary according to conventional diagnostics ${ }^{1}$.

\footnotetext{
${ }^{1}$ The test results are available from the author upon request.
}

\section{Estimation results}

For estimation purposes, we add a constant $\left(\alpha_{0}\right)$ and the parameters $\alpha_{1}$ and $\alpha_{2}$ to equation (4) to cover the reaction towards the lagged exchange rate and the differences in the monetary base of both jurisdictions together with an error term $\left(\varepsilon_{t}\right)$. Since the right hand side variables are lagged by one period, we can exclude the presence of reverse causality, i.e., a central bank reaction to unwarranted developments in the exchange rate.

$e r_{t}=\alpha_{0}+\alpha_{1} e r_{t-1}+\alpha_{2}\left(r_{U S_{t-1}}-r_{E A_{t-1}}\right)+\varepsilon_{t}$

Please note that equation (5) implicitly assumes that an increase in the Fed monetary base has the same effect on the exchange rate as an equivalent reduction in the monetary base of the ECB and vice versa. But possibly the exchange rate adjustment is asymmetric in a sense that 1) changes in the monetary base in one jurisdiction are different from those in the other and 2) exchange rate adjustments towards expansions differ from those of reductions.

$e r_{t}=\alpha_{0}+\alpha_{1} e r_{t-1}+\alpha_{21} r_{U S_{t-1}}+\alpha_{22} r_{E A_{t-1}}+\varepsilon_{t}$.

To account for the first asymmetry, we introduce Fed and ECB specific parameters $\left(\alpha_{21}\right.$ and $\alpha_{22}$, respectively) in equation (6). Note, however, that $\alpha_{22}$, the reaction to an increase of the monetary base of the ECB, should now have an 
significantly negative impact on the exchange rate, since it should depreciate the Euro, in contrast to $\alpha_{2}$ and $\alpha_{21}$.

$$
\begin{aligned}
& e r_{t}=\alpha_{0}+\alpha_{1} e r_{t-1}+ \\
& +\left\{\begin{array}{c}
\alpha_{21_{e e}} r_{U S_{t-1 e e}}+\alpha_{22_{e e}} r_{E A_{t-1} e e} \\
\alpha_{21_{e r}} r_{U S_{t-1 e r}}+\alpha_{22_{e r}} r_{E A_{t-1 e r}} \\
\alpha_{21_{r e}} r_{U S_{t-1} e}+\alpha_{22_{r e}} r_{E A_{t-1} e} \\
\alpha_{21_{r r}} r_{U S_{t-1} r r}+\alpha_{22_{r r}} r_{E A_{t-1} r}
\end{array}\right\}+\varepsilon_{t} .
\end{aligned}
$$

The second asymmetry is accounted for by introducing a state variable if the monetary base in one jurisdiction is expansionary $(e)$ or restrictive $(r)$, meaning whether the monetary base is rising or decreasing relative to the prior week. Moreover, interactions are modeled explicitly in equation (7) by observing the state of the monetary base by both central banks simultaneously. This yields four combinations: first, both central banks are expansionary, second and third, one central bank is expansionary, while the other is restrictive and, fourth, both are restrictive. In the following, we will present the results for the estimations of equation (5) to (7). We will always present results for three different sample periods. First, the whole sample period 2005W1-2015W2, second, for the pre-crisis period up to the Lehman collapse in 2008W38, third, the period thereafter labeled as crisis period. The fourth estimation is the robustness check of the crisis period starting in $2009 \mathrm{~W} 20$, which is essentially the period where both central banks faced the zero lower bound. We will first start with presenting the exchange rate adjustments towards the common response before turning to the asymmetries in the following subsection.

3.1. Common response. Without any asymmetries, i.e., using a common estimation parameter for both central banks monetary bases, yields the results presented in Table 1. It is obvious that in all three sample periods, the lagged exchange rate is a good predictor for the current rate. Moreover, the differences in the monetary base are estimated to have no significant effect on the exchange rate when the pre-crisis and whole sample period is used. The latter is exactly what we have expected, since the monetary base or its differences were no (implicit) policy target by the central banks before the crisis. But when it comes to the crisis period, we indeed find the expected significantly positive response of the exchange rate towards balance sheet differences. However, the influence seems to be rather low, as a one percent increase of the Fed monetary base compared to the ECB leads only to an depreciation of the Dollar by 0.036 percent. This result is only marginally higher ( 0.041 percent) when the analysis is started after the ECB lowered the key interest rate to one percent.
Table 1. Common response

\begin{tabular}{|c|c|c|c|c|}
\hline & $\begin{array}{c}\text { Whole sample } \\
\text { period }\end{array}$ & $\begin{array}{c}\text { Pre-crisis } \\
\text { period }\end{array}$ & $\begin{array}{c}\text { Crisis } \\
\text { period }\end{array}$ & $\begin{array}{c}\text { Crisis } \\
\text { period 1 }\end{array}$ \\
\hline Constant & 0.002 & 0.002 & 0.003 & -0.001 \\
& $(0.003)$ & $(0.003)$ & $(0.004)$ & $(0.004)$ \\
\hline \multirow{2}{*}{$r_{t-1}$} & $0.990^{* * *}$ & $0.993^{* *}$ & $0.986^{* * *}$ & $0.999^{* * *}$ \\
$(0.009)$ & $(0.010)$ & $(0.015)$ & $(0.014)$ \\
\hline$r_{U S_{t-1}}$ & 0.018 & -0.022 & $0.036^{*}$ & $0.041^{*}$ \\
$-r_{E A_{t-1}}$ & $(0.015)$ & $(0.024)$ & $(0.020)$ & $(0.019)$ \\
\hline$R^{2}$ & 0.960 & 0.983 & 0.930 & 0.947 \\
\hline$T$ & 531 & 193 & 338 & 304 \\
\hline
\end{tabular}

Notes: dependent variable $e r_{t} ; * / * * / * * *$ signals significance at the $10 \backslash \% / 5 \backslash \% / 1 \backslash \%$ level; whole sample period: $2005 \mathrm{~W} 1-$ 2015W10, pre-crisis period: 2005W1-2008W37, crisis period: 2008W38-2015W10, crisis period 1: 2009W20-2015W10.

3.2. Central bank specific response. When accounting for a potential asymmetric influence of the central banks on the exchange rate, the results with respect to the constant and the lagged exchange rate remain almost unchanged (Table 2). However, splitting up the parameters leads to the result that altering the monetary base of the Fed does not have any significant effect on the exchange rate irrespectively which sample period is chosen. In contrast to the Euro area the exchange rate response towards an adjustment of the monetary base in the crisis is with an elasticity of 0.051 even stronger than before. However, when accounting only for the period starting in week 20 of the year 2009 the response is slightly lower than before ( 0.038 percent $)$ and even insignificant.

Table 2. Central bank specific response

\begin{tabular}{|c|c|c|c|c|}
\hline & $\begin{array}{c}\text { Whole sample } \\
\text { period }\end{array}$ & $\begin{array}{c}\text { Pre-crisis } \\
\text { period }\end{array}$ & $\begin{array}{c}\text { Crisis } \\
\text { period }\end{array}$ & $\begin{array}{c}\text { Crisis } \\
\text { period 1 }\end{array}$ \\
\hline \multirow{2}{*}{ Constant } & $0.005^{*}$ & 0.002 & 0.003 & -0.000 \\
& $(0.003)$ & $(0.003)$ & $(0.004)$ & $(0.004)$ \\
\hline \multirow{2}{*}{$e r_{t-1}$} & $0.990^{* * *}$ & $0.993^{* *}$ & $0.987^{* * *}$ & $0.998^{* * *}$ \\
& $(0.009)$ & $(0.010)$ & $(0.015)$ & $(0.014)$ \\
\hline \multirow{2}{*}{$r_{U S_{t-1}}$} & 0.004 & -0.105 & 0.022 & 0.056 \\
& $(0.027)$ & $(0.066)$ & $(0.031)$ & $(0.036)$ \\
\hline$r_{E A_{t-1}}$ & -0.027 & 0.004 & $-0.051^{*}$ & -0.038 \\
\hline$R^{2}$ & $(0.019)$ & $(0.024)$ & $(0.027)$ & $(0.028)$ \\
\hline$T$ & 0.960 & 0.983 & 0.930 & 0.947 \\
\hline
\end{tabular}

Notes: dependent variable $e r_{t} ; * / * * / * * *$ signals significance at the $10 \backslash \% / 5 \backslash \% / 1 \backslash \%$ level; whole sample period: $2005 \mathrm{~W} 1-$ 2015W10, pre-crisis period: 2005W1-2008W37, crisis period: 2008W38-2015W10, crisis period 1: 2009W20-2015W10.

3.3. State specific response. Besides, adding the stance of monetary policy in both jurisdictions, thus, whether monetary policy is expansive or restrictive, allows us a further breakdown of the results of subsection 3.2. Before interpreting the results, we present the number of observations in each state for the three sample periods, since too low observations in one state might lead to inconclusive results. However, from Table 3, it becomes obvious that in each state and sample period, there are more than 40 observations, which should be sufficient to generate reliable results. Table 3 also shows that Fed and ECB monetary policy were almost equally distributed in expansive and re- 
strictive periods before the crisis and changed to a more expansive policy in the crisis, as we have also seen in Figure 2, with the Fed being even more expansive than the ECB up to date.

Table 3. State numbers

\begin{tabular}{|c|c|c|c|c|}
\hline & $\begin{array}{c}\text { Whole } \\
\text { sample } \\
\text { period }\end{array}$ & $\begin{array}{c}\text { Pre-crisis } \\
\text { period }\end{array}$ & Crisis period & $\begin{array}{c}\text { Crisis period } \\
1\end{array}$ \\
\hline$e e$ & 151 & 58 & 93 & 83 \\
\hline$e r$ & 153 & 41 & 112 & 99 \\
\hline$r e$ & 109 & 48 & 61 & 56 \\
\hline$r r$ & 118 & 46 & 72 & 66 \\
\hline$T$ & 531 & 193 & 338 & 304 \\
\hline
\end{tabular}

Notes: number of observations in each state; $e=$ expansive monetary policy, $r=$ restrictive monetary policy, first index for U.S., second index for the Euro area.

Dividing the sample into the four different states leads to the result (Table 4) that almost in no state the monetary base has an influence on the exchange rate. However, there are three exceptions:

First, for the whole sample and even more for the precrisis period, a restrictive Fed policy, while that of ECB is expansive, seems to have had the effect of depreciating the Dollar in contrast to what we would have expected. But this result is solely driven by the pre-crisis period, a period where the interest rate and not the monetary base was the policy target of both central banks. In the crisis period, this puzzling result changes to the expected positive parameter, which, however, remains insignificant.

The second significantly estimated parameter concerns the crisis period. An expansion of the ECB's monetary base seems to have had the expected depreciating effect on the Euro if the Fed is at the same time restrictive. The elasticity is with -0.163 also quite high compared to the ones estimated in the previous subsections, thus, in this state, the ECB has a substantial influence on the exchange rate. The estimate is only marginally lower when adjusting the sample to start in week 20 of the year 2009. In contrast, the Fed has no option to directly depreciate the Dollar. However, they could at least avoid the Dollar to appreciate by being also expansive when the ECB is.

However, the Fed can influence the exchange rate when both central banks are restrictive in the sample starting after both central banks faced the zero lower bound (crisis period 1). In this case, only the Fed has the option to significantly appreciate the Dollar towards the Euro. This is good news for the Fed, since they are enabled to dampen foreign demand and export prices when trying to end the period of quantitative easing, which is possibly accompanied with rising inflation rates.
Table 4. State specific response

\begin{tabular}{|c|c|c|c|c|}
\hline & $\begin{array}{c}\text { Whole sample } \\
\text { period }\end{array}$ & $\begin{array}{c}\text { Pre-crisis } \\
\text { period }\end{array}$ & Crisis period & Crisis period 1 \\
\hline Constant & $\begin{array}{c}0.003 \\
(0.003)\end{array}$ & $\begin{array}{c}0.003 \\
(0.003)\end{array}$ & $\begin{array}{c}0.004 \\
(0.004)\end{array}$ & $\begin{array}{l}-0.001 \\
(0.004)\end{array}$ \\
\hline$e r_{t-1}$ & $\begin{array}{l}0.989^{* * \star} \\
(0.009)\end{array}$ & $\begin{array}{c}0.996^{* * *} \\
(0.010)\end{array}$ & $\begin{array}{l}0.984^{\star \star \star} \\
(0.015)\end{array}$ & $\begin{array}{c}0.999^{* * *} \\
(0.014)\end{array}$ \\
\hline$r_{U S_{t-1 e e}}$ & $\begin{array}{c}0.038 \\
(0.044)\end{array}$ & $\begin{array}{c}0.060 \\
(0.153)\end{array}$ & $\begin{array}{c}0.048 \\
(0.050)\end{array}$ & $\begin{array}{c}0.058 \\
(0.069)\end{array}$ \\
\hline$r_{E A_{t-1} e e}$ & $\begin{array}{l}-0.050 \\
(0.045)\end{array}$ & $\begin{array}{l}-0.043 \\
(0.073)\end{array}$ & $\begin{array}{l}-0.063 \\
(0.057)\end{array}$ & $\begin{array}{c}0.019 \\
(0.066)\end{array}$ \\
\hline$r_{U S_{t-1 e r}}$ & $\begin{array}{l}-0.005 \\
(0.047)\end{array}$ & $\begin{array}{l}-0.100 \\
(0.122)\end{array}$ & $\begin{array}{c}0.020 \\
(0.055)\end{array}$ & $\begin{array}{c}0.011 \\
(0.060)\end{array}$ \\
\hline$r_{E A_{t-1} e r}$ & $\begin{array}{l}-0.039 \\
(0.033)\end{array}$ & $\begin{array}{l}-0.012 \\
(0.054)\end{array}$ & $\begin{array}{l}-0.040 \\
(0.043)\end{array}$ & $\begin{array}{c}-0.062 \\
(0.045)\end{array}$ \\
\hline$r_{U S_{t-1} r e}$ & $\begin{array}{l}-0.164^{* *} \\
(0.069)\end{array}$ & $\begin{array}{c}-0.405^{\star \star \star} \\
(0.151)\end{array}$ & $\begin{array}{l}-0.092 \\
(0.085)\end{array}$ & $\begin{array}{c}0.095 \\
(0.099)\end{array}$ \\
\hline$r_{E A_{t-1} r e}$ & $\begin{array}{l}-0.028 \\
(0.036)\end{array}$ & $\begin{array}{l}-0.015 \\
(0.034)\end{array}$ & $\begin{array}{l}-0.163^{*} \\
(0.097)\end{array}$ & $\begin{array}{c}-0,154^{*} \\
(0.89)\end{array}$ \\
\hline$r_{U S_{t-1} r r}$ & $\begin{array}{c}0.109 \\
(0.069)\end{array}$ & $\begin{array}{c}0.056 \\
(0.169)\end{array}$ & $\begin{array}{c}0.109 \\
(0.081)\end{array}$ & $\begin{array}{l}0.141^{*} \\
(0.081)\end{array}$ \\
\hline$r_{E A_{t-1 r r}}$ & $\begin{array}{c}0.001 \\
(0.039)\end{array}$ & $\begin{array}{c}0.035 \\
(0.057)\end{array}$ & $\begin{array}{l}-0.017 \\
(0.052)\end{array}$ & $\begin{array}{l}-0.011 \\
(0.050)\end{array}$ \\
\hline$R^{2}$ & 0.961 & 0.984 & 0.931 & 0.948 \\
\hline$T$ & 531 & 193 & 338 & 304 \\
\hline
\end{tabular}

Notes: dependent variable $e r_{t} ; * / * * / * * *$ signals significance at the $10 \backslash \% / 5 \backslash \% / 1 \backslash \%$ level; whole sample period: $2005 \mathrm{~W} 1-$ 2015W10, pre-crisis period: 2005W1-2008W37, crisis period: 2008W38-2015W10, crisis period 1: 2009W20-2015W10.

\section{Conclusions}

In this article, it is shown that with the collapse of the investment bank Lehman Brothers, the Fed and the ECB at least implicitly used their monetary base to stimulate the economy. This has become necessary, since the key interest rates were at the risk or have even hit the zero lower bound. But such a policy has also an effect on the exchange rate of between both jurisdictions, which is equivalent to the well-known interest rate parity in normal times.

This balance sheet parity is indeed able to explain a part of the exchange rate movement in the crisis period, while there is no influence of the monetary base before the crisis. The results further indicate that it is especially the ECB that can influence the exchange rate, while the impact of the Fed monetary policy remains insignificant. The strongest influence of the ECB on the exchange rate is given by a expansionary policy, while the Fed is trying to normalize its balance sheet, a situation which we observe since the beginning of 2015, where the Fed tries to exit from its expansionary monetary policy, while the ECB has introduced a large scale bond buying programme and even prolonged it two times at least to the end of 2017. 


\section{References}

1. Baba, N. and Packer, F. (2009). From Turmoil to Crisis: Dislocations in the FX Swap Market Before and After the Failure of Lehman Brothers, Journal of International Money and Finance, 28 (8), pp. 1350-1374.

2. Campbell, J., Evans, C., Fisher, J., Justiniano, A., Calomiris, C. and Woodford, M. (2012). Macroeconomic Effects of Federal Reserve Forward Guidance, Brookings Papers on Economic Activity, Spring 2012, pp. 1-80.

3. Chen, Q., Filardo, A., He, D. and Zhu, F. (2012). International Spillovers of Central Bank Balance Sheet Policies, BIS Paper No., p. 66.

4. Fratzscher, M., Lo Duca, M. and Straub, R. (2013). On the international spillovers of US Quantitative Easing, ECB Working Paper No. 1557.

5. Hanson, S. and Stein, J. (2012). Monetary Policy and Long-Term Real Rates, FEDS Working Paper No. 2012-46.

6. Joyce, M., Lasaosa, A., Stevens, I. and Tong, M. (2011). The Financial Market Impact of Quantitative Easing in the United Kingdom, International Journal of Central Banking, September 2011, pp. 113-161.

7. Levich, R. (2011). Evidence on Financial Globalization and Crises: Interest Rate Parity, NYU Working Paper No. 2451/29949.

8. Neely, C. (2010). Unconventional Monetary Policy Had Large International Effects, Fed St. Louis Working Paper 2010-018G.

9. Swanson, E. and Williams, J. (2014). Measuring the Effect of the Zero Lower Bound on Medium- and LongerTerm Interest Rates, American Economic Review, 104 (10), pp. 3154-3185. 